\title{
Influence of Bacillus spp. Enzymes on Ultra High Temperature-treated Milk Proteins
}

\author{
B. JANŠTOVÁ, J. LUKÁŠOVÁ, M. DRAČKOVÁ, L. VORLOVÁ \\ Department of Milk Hygiene and Technology, Faculty of Veterinary Hygiene and Ecology, \\ University of Veterinary and Pharmaceutical Sciences Brno
}

Received January 7,2004

Accepted July 29, 2004

Abstract

Janštová, B., J. Lukášová, M. Dračková, L. Vorlová: Influence of Bacillus spp. Enzymes on Ultra High Temperature-treated Milk Proteins. Acta Vet. Brno 2004, 73: 393-400.

A model case of long-life half-fat milk contamination with spores of 15 strains of $B$. licheniformis, B. subtilis a B. cereus isolated from farm environment and from raw milk was used to determine proteolysis by measuring the changes in milk protein contents. The methods of infrared spectroscopy, free tyrosine using Lowry's method according to Juffs and setting of decrease in casein fractions using the SDS-PAGE were employed.

Under storage temperature of $4{ }^{\circ} \mathrm{C}$ no proteolysis was recorded. However, under storage temperature of $24{ }^{\circ} \mathrm{C}$ the following changes in comparison with initial values were recorded after 3 weeks: a decrease in protein contents from $34.60 \mathrm{~g} \cdot 1^{-1}$ to $29.46-32.86 \mathrm{~g} \cdot \mathrm{l}^{-1}$ and increased free tyrosine contents from $0.65 \mathrm{mg} \cdot \mathrm{ml}^{-1}$ to $2.13-1.59 \mathrm{mg} \cdot \mathrm{ml}^{-1}$ depending on Bacillus spp. type. It was detected that milk heating at a temperature of $100^{\circ} \mathrm{C}$ for $10 \mathrm{~min}$ and at $135^{\circ} \mathrm{C}$ for $5 \mathrm{~s}$, respectively, the spores of resistant strains Bacillus licheniformis may survive and show proteolytic activity.

When monitoring the reduction of casein fractions it was found that the $\kappa$-casein was the most quickly broken down to $7.43 \%$. The values of $\beta$-casein dropped to $27.53 \%$ and $\alpha$-casein to $43.95 \%$. Under storage temperature of $4{ }^{\circ} \mathrm{C}$ the reduction of all casein fractions was lower. A reduction to $79.42 \%$ for $\kappa$-casein, $78.30 \%$ for $\beta$-casein and $85.71 \%$ for $\alpha$-casein was recorded.

The intensity of changes was dependent on species and strain of Bacillus spp. used, on storage temperature and heat inactivation of spores. The initial spore concentration made itself felt, too.

Proteolysis, Bacillus spores, Bacillus licheniformis, casein

Aerobic and facultative anaerobic, sporulating gram-positive bacteria Bacillus spp. represent important contaminants of raw milk, mainly from the hygienic and technological point of view, some of them even from the point of view of human health.

Spores of Bacillus spp. appear regularly in stable environment and they usually represent a secondary contamination of milk during milking process. Many representatives of the Bacillus strain create a part of the psychrotrophic microflora of milk. B. licheniformis and B. cereus are the most frequently isolated types of the Bacillus from raw milk (Crielly et al. 1994; Phillips and Griffiths 1986). Páčová et al. (1996) found the most frequent occurrence of the type B. licheniformis. The occurrence of other types is lower (Lukášová et al. 2001; Vyletělová et al. 2001).

The post-pasteurization contamination is by spores from raw milk that either passed pasteurizing or come from the plant environment. Spores of thermostable bacteria may be introduced into the product even in the course of the technologic process. Microorganisms Bacillus spp. may also appear in UHT milk, as stated e.g. by B ahout (2000), who found spores in $18.3 \%$ of examined samples in the quantity of up to $2.6 \times 102 \cdot \mathrm{ml}^{-1}$. Vyle tělová (2001) monitored - on the basis of ribo-typing - the occurrence of $B$. licheniformis in milk up to the final product, the UHT milk, and in consideration of its frequency she supposes its penetration from the initial stage of production, while the origin of $B$. cereus in UHT milk 
cannot be clearly explained - it may come from the initial stage of production or the milk was re-contaminated in the course of processing.

Bacillus spp. is a very difficult part of raw milk microflora, taking into consideration the problematic removal of its spores, related to their thermoresistance. The spores may also be partially damaged by pasteurization temperature, but they usually do not survive sterilization and the UHT process. An important characteristics of Bacillus spp. is the ability of vegetative cells to produce - after multiplication - thermostable extracellular enzymes (Meer et al. 1991; Ipsen et al. 2000), that - due to their proteolytic and lipolytic activity. These affect the nutritional and sensorial characteristics of products even when viable bacteria are absent (Boor et al. 1998). According to Brown (2000) Bacillus spp. are the microorganisms causing significant economic losses.

Proteolysis of casein substances is one of the main features in proteolysis of milk proteins. For casein affection there $10^{4}-10^{8}$ bacterial cells in $1 \mathrm{ml}$ of milk are needed (Marth and Steele 1998). Kappa-casein is subject to the fastest hydrolysis of milk proteins. In the course of 7 days and under storage temperature of $20^{\circ} \mathrm{C}$ it is completely lost, while para $\kappa$-casein is formed. The reduction of $\beta$-casein reaches $70 \%$. Alfa-casein remains stable for the longest time and its loss is minimal (Dalgleish 1990). In comparison with fractions of $\kappa$-casein, $\alpha$-lactalbumin and $\beta$-lactoglobulin are resistant (Swais good 1993; Madsen and Quist 1997).

The effects of UHT milk treatment methods were monitored by Kelly and Foley (1997), who recorded a more efficient inactivation of bacterial proteinase when using an indirect UHT method. García-Risco et al. (1999) recorded - in the course of storage at a temperature of $25^{\circ} \mathrm{C}$ - more significant proteolysis in UHT skimmed milk in comparison with full milk. They recommend for this fact to be taken into consideration when setting the parameters of the UHT process depending on product type.

The influences of proteolytic enzymes cause many defects of milk and dairy products, such as sweet curdling, colour and odour defects. A specifically monitored defect is gelformation by UHT milk (Datta and Deeth 2001; Dalgleish 1990; McMahon 1996; $\mathrm{Kav}$ an a h et al.2000). The defects are detected at the moment of reaching the concentration of microorganisms of $5.10^{5}-10^{7} \mathrm{CFU} \cdot \mathrm{ml}^{-1}$ (Vyletělová et al. 2000; Marth and Steele 1998).

\section{Materials and Methods}

Collection strains of the Institute of Milk Hygiene and Technology, Faculty of Veterinary Hygiene and Ecology Brno, were used for the tests. Fifteen strains of Bacillus spp. were used isolated in the farm environment and from raw milk. Each test was performed with 5 strains of $B$. licheniformis, 5 strains of B. subtilis and 5 strains of $B$. cereus. Identification of isolated strains was performed by Lukášová et al. (2001), phenotype characteristics were tested on the basis of conventional growth tests. The long-life semi-full milk from the market was used as a medium for contamination with spores of Bacillus spp.

Acrylamide, bisacrylamide, ammonium persulfate, TEMED, bromophenol blue, glycine, Tris (hydroxymethyl)aminomethane, 2-mercapthoethanol, Coomasie brilliant blue R-250 were supplied by the company Bio-Rad Laboratories (Richmond, CA). All chemical substances used were of p. a. grade.

Inoculation of tested milk was performed using spore suspensions Bacillus spp. without thermo-inactivation, inoculated into the UHT milk in such a quantity so as to reach the concentration of spores of $10^{2}, 10^{1},<10^{1}$ in $1 \mathrm{ml}$ of milk. Then, the spore suspensions were heated to a temperature of $100{ }^{\circ} \mathrm{C}$ with exposure for 10 min and to a temperature of $135^{\circ} \mathrm{C}$ with exposure for 5 seconds and inoculated to milk in identical quantity. Samples of milk were stored in closed sterile glass sampling bottles at a temperature of $24{ }^{\circ} \mathrm{C}$ in thermostat and at temperature of $4{ }^{\circ} \mathrm{C}$ in refrigerator. In order to be able to compare the growth dynamics of microorganisms growth and changes in values of monitored features, the microbiological examination of milk samples was performed - setting the total number of sporulating microorganisms. The Plate Count Agar (HiMedia, India) was used. The protein contents settings were performed at one-week intervals plus free tyrosine contents was set daily in the course of the first week. The samples were stored for three months.

The protein contents was measured on the basis of the infra-red spectroscopy method MIR using the MilkoScan 104 device with multi-detection application (A/S N. Foss Electric, Denmark), using the wavelength of $645 \mathrm{~nm}$. Before examination, the samples were conserved by potassium bichromate $\left(\mathrm{K}_{2} \mathrm{Cr}_{2} \mathrm{O}_{7}\right)$ in $0.6 \mathrm{~g} \cdot \mathrm{l}^{-1}$ of milk. As 
a second method of bacterial proteolysis free tyrosine was measured by the Lowry's method according to Juffs (1973) with Folin-Ciocalteu phenol reagent, showing blue colour when mixed with the free tyrosine.The blue colour was measured using the spectrum photometer Helios $\beta$ (Unicam, England, UK).

The decrease in casein fractions was monitored using the spore suspension $B$. licheniformis at a concentration of $10^{1} \cdot \mathrm{ml}^{-1}$. The samples were stored at the above temperatures for a period of $1-4$ months. In order to separate casein from whey proteins, the samples were precipitated with $10 \%$ acetic acid to $\mathrm{pH} 4.6$. The residual fat was removed from the casein precipitate by three-time repeated washing in the solution of methylene dichloride - water (1:1) and by separation at $4500 \mathrm{~g}$ of $15 \mathrm{~min}$. The final casein precipitate was processed using the lyophilizator Lyovac GT 2 (Amsco/Finn-Aqua, Finland) (López-Fandiño et al. 1993). The lyophilized casein was dissolved in Tris- $\mathrm{HCl}(\mathrm{pH} 8.8)$ and sample buffer was added (2.4 ml Tris- $\mathrm{HCl} \mathrm{pH} \mathrm{6.8,2} \mathrm{ml} 10 \%$ SDS (w/v), along with $1 \mathrm{ml}$ glycerol, $4.4 \mathrm{ml}$ distilled water, $0.1 \mathrm{ml}$ bromophenol blue) at the rate of 1:4. The samples were boiled for $2 \mathrm{~min}$. The separation of casein fractions was performed using separation gels $(15 \% \mathrm{~T}, 2.6 \% \mathrm{C})$ and concentrating gels (3\% T, 2.6\% C) (Laemli 1970) while using the Mini-Protean III Cell Electrophoresis apparatus (Bio-Rad Laboratories, Richmond, CA). Separation buffer (30.3 g Tris, $144 \mathrm{~g}$ glycine, $10 \mathrm{~g}$ SDS completed up to 1 litre with distilled water) was used for migration, diluted 1:9 with distilled water. Electrophoresis was performed at $110 \mathrm{~V}$ at room temperature until bromophenol blue reached the end of the gel. Then, the gels were coloured with Commassie Brilliant Blue R-250 (450 ml ethanol, $100 \mathrm{ml}$ acetic acid, $450 \mathrm{ml}$ distilled water, $0.5 \mathrm{~g}$ Coomasie Blue R-250). The samples were coloured overnight with consequent colour removal $(250 \mathrm{ml}$ ethanol, $100 \mathrm{ml}$ acetic acid, $650 \mathrm{ml}$ distilled water). Then, the samples were dried, scanned and assessed using the computer program Image Quant 5.0 (Molecular Dynamics, USA). Quantification was performed on the basis of pixel density of individual areas of casein fraction bands. The decrease of individual casein fractions was always assessed within the scope of one coloured gel with applied samples, stored at given temperature from all extractions in the course of the given time period. The samples without Bacillus licheniformis were applied first. The coloration intensity (pixel density) was considered to be $100 \%$. Values of pixels, measured for the other samples, were always related to the given value and re-calculated to percent data.

While assessing the trials, the average values from results established at 5 strains of each type of Bacillus spp. were calculated. Statistical significance of differences at the levels of $p<0.01$ and $p<0.05$ for individual indicators was performed by using the Statistic and Graphic System STAT Plus (Matoušková et al. 1992). Data assessment was performed by dispersion analysis and by methods of consequent testing - the Scheffe's method of contracts and Tukey's test of significance of differences were used. In order to reach correctness of the results, the Box - Cox transformation was applied by dispersion analysis to the data so as to meet the condition of basic classification normality. Before the dispersion analysis it was necessary to verify the homogeneity of dispersion of compared selections. Bartlett's test was used for this purpose.

\section{Results and Discussion}

The decrease of protein contents due to influence of proteolytic enzymes was recorded using the MilcoScan device only at a storage temperature of $24^{\circ} \mathrm{C}$ and it corresponded with the growth of the number of microorganisms. More significant proteolysis was found in samples with higher initial contents of inoculated thermally inactivated spores in milk. A smaller range was recorded in samples with sporadic spore presence.

When using the highest concentration of spores and storage for 3 weeks (see Table 1a), the examined strains of $B$. licheniformis caused a significant reduction of milk protein content depending on initial concentration used - from $34.60 \mathrm{~g} \cdot \mathrm{1}^{-1}$ to $32.58-31.40-31.18$ $\mathrm{g} \cdot 1^{-1}$ of milk. The proteolytic effect of $B$. subtilis enzymes may be assessed in comparison with the other examined types as the least significant one, the protein contents found depending on initial spores concentration used - the values of $33.22-33.26-32.86 \mathrm{~g} \cdot 1^{-1}$ of milk. When monitoring the milk samples containing $B$. cereus spores a significant reduction in protein contents was recorded for all the examined strains. The values of $31.26-29.79-$ $29.46 \mathrm{~g} \cdot 1^{-1}$ of milk were found. Even with initial contents of spores in milk of $<10^{1} \cdot \mathrm{ml}^{-1}$ the detected protein contents was very low (Table 1a). Significant $(p<0.05)$ or highly significant $(p<0.01)$ differences were recorded among the effects of enzymes of individual monitored types of Bacillus spp.

When storing the samples at temperature of $4{ }^{\circ} \mathrm{C}$ the reduction of proteins did not occur due to any of the monitored types of Bacillus spp. - in comparison with the initial protein contents. The numbers found are comparable with control samples.

The MilcoScan device was used for determination of proteolysis also by Kelly and Foley (1997), who monitored the influence of native proteolytic enzymes of milk. The questions of 
Table 1

Content of the proteins $\left(\mathrm{g} \cdot \mathrm{l}^{-1}\right)$ in the UHT milk with spores of B. licheniformis, B. subtilis, B. cereus in the course of storage (week) at $24^{\circ} \mathrm{C}$

\begin{tabular}{|c|c|c|c|c|}
\hline \multirow{2}{*}{ Species } & \multirow{2}{*}{ week } & \multicolumn{3}{|c|}{ Initial concentration of spores in $1 \mathrm{ml} \mathrm{milk}$} \\
\hline & & $10^{2} \pm \mathrm{SD}$ & $10^{1} \pm \mathrm{SD}$ & $<10^{1} \pm \mathrm{SD}$ \\
\hline \multicolumn{5}{|c|}{ a) without inactivation of spores } \\
\hline & & Initial proteins content & 34.60 & \\
\hline \multirow[t]{3}{*}{ B. licheniformis } & 1 & $33.90 \pm 0.46$ & $33.98 \pm 0.48$ & $33.98 \pm 1.09$ \\
\hline & 2 & $32.44 \pm 1.08$ & $32.42 \pm 1.08$ & $33.88 \pm 0.46$ \\
\hline & 3 & $31.18 \pm 1.52$ & $31.40 \pm 1.19$ & $32.58 \pm 1.25$ \\
\hline \multirow[t]{3}{*}{ B. subtilis } & 1 & $33.82 \pm 1.28$ & $33.86 \pm 1.46$ & $33.84 \pm 1.15$ \\
\hline & 2 & $33.52 \pm 1.18$ & $33.70 \pm 1.25$ & $33.64 \pm 1.36$ \\
\hline & 3 & $32.86 \pm 1.38$ & $33.26 \pm 1.31$ & $33.22 \pm 1.38$ \\
\hline \multirow[t]{3}{*}{ B. cereus } & 1 & $32.64 \pm 0.98$ & $33.52 \pm 1.33$ & $33.96 \pm 1.03$ \\
\hline & 2 & $30.36 \pm 1.94$ & $30.48 \pm 2.20$ & $32.34 \pm 1.06$ \\
\hline & 3 & $29.46 \pm 2.00$ & $29.76 \pm 2.14$ & $31.26 \pm 2.26$ \\
\hline \multicolumn{5}{|c|}{ b) inactivation of spores - temperature $100^{\circ} \mathrm{C}$, time $10 \mathrm{~min}$} \\
\hline & & Initial proteins content & 34.50 & \\
\hline \multirow[t]{3}{*}{ B. licheniformis } & 1 & $33.60 \pm 0.55$ & $34.00 \pm 0.00$ & $34.40 \pm 0.06$ \\
\hline & 2 & $33.40 \pm 0.00$ & $33.40 \pm 0.10$ & $34.40 \pm 0.06$ \\
\hline & 3 & $31.10 \pm 0.72$ & $33.30 \pm 0.06$ & $34.30 \pm 0.06$ \\
\hline \multirow[t]{3}{*}{ B. subtilis } & 1 & $34.40 \pm 0.06$ & $34.40 \pm 0.06$ & $34.50 \pm 0.06$ \\
\hline & 2 & $34.40 \pm 0.10$ & $34.40 \pm 0.12$ & $34.40 \pm 0.00$ \\
\hline & 3 & $34.40 \pm 0.12$ & $34.30 \pm 0.12$ & $34.30 \pm 0.00$ \\
\hline \multirow[t]{3}{*}{ B. cereus } & 1 & $34.40 \pm 0.06$ & $34.40 \pm 0.06$ & $34.50 \pm 0.00$ \\
\hline & 2 & $34.40 \pm 0.00$ & $34.40 \pm 0.00$ & $34.40 \pm 0.00$ \\
\hline & 3 & $34.30 \pm 0.00$ & $34.30 \pm 0.00$ & $34.30 \pm 0.00$ \\
\hline \multicolumn{5}{|c|}{ c) inactivation of spores - temperature $135^{\circ} \mathrm{C}$, time $5 \mathrm{~s}$} \\
\hline & & Initial proteins content & 34.60 & \\
\hline \multirow[t]{3}{*}{ B.licheniformis } & 1 & $34.30 \pm 0.00$ & $34.30 \pm 0.00$ & $34.35 \pm 0.07$ \\
\hline & 2 & $34.15 \pm 0.07$ & $34.25 \pm 0.14$ & $34.35 \pm 0.00$ \\
\hline & 3 & $33.05 \pm 1.77$ & $33.80 \pm 0.57$ & $34.30 \pm 0.07$ \\
\hline \multirow[t]{3}{*}{ B. subtilis } & 1 & $34.60 \pm 0.00$ & $34.35 \pm 0.07$ & $34.40 \pm 0.14$ \\
\hline & 2 & $34.50 \pm 0.00$ & $34.40 \pm 0.14$ & $34.35 \pm 0.21$ \\
\hline & 3 & $34.40 \pm 0.14$ & $34.40 \pm 0.00$ & $34.40 \pm 0.00$ \\
\hline \multirow[t]{3}{*}{ B. cereus } & 1 & $34.45 \pm 0.07$ & $34.35 \pm 0.07$ & $34.45 \pm 0.07$ \\
\hline & 2 & $34.45 \pm 0.07$ & $34.40 \pm 0.00$ & $34.40 \pm 0.00$ \\
\hline & 3 & $34.35 \pm 0.07$ & $34.35 \pm 0.07$ & $34.45 \pm 0.07$ \\
\hline
\end{tabular}

protein contents in milk caused by activities of lytic enzymes were also studied by Corzo et al. (1994), Recio et al. (2000), Zhao et al. (1998), Madsen and Qvist (1997).

Lower values of free tyrosine (Table 2a) were found in samples with sporadic occurrence of spores, while a significant increase was detected with higher spore contents. Changes were monitored as soon as from the second day of monitoring, when the average number of sporulating bacteria reached $10^{4}-10^{5} \mathrm{CFU} \cdot \mathrm{ml}^{-1}$ during tests with all the monitored types of bacilli. In the course of storage of milk samples with spores of B. licheniformis - an increase of free tyrosine was detected after a period of 28 days depending on initial spore concentration up to $1.34-1.59-1.58 \mathrm{mg} \cdot \mathrm{ml}^{-1}$. The highest proteolytic activity was recorded for B. cereus, where free tyrosine values of 2.09 and $2.13 \mathrm{mg} \cdot \mathrm{ml}^{-1}$ were detected at higher 
Table 2a

Content of the free tyrosine $\left(\mathrm{mg} \cdot \mathrm{ml}^{-1}\right)$ in the UHT milk with spores of $B$. licheniformis, $B$. subtilis, B. cereus in the course of storage (day) at $24^{\circ} \mathrm{C}$

\begin{tabular}{|c|c|c|c|c|c|c|c|c|}
\hline \multirow{2}{*}{$\begin{array}{l}\text { Initial concentration } \\
\text { of spores in } 1 \mathrm{ml} \\
\text { milk }\end{array}$} & \multicolumn{8}{|c|}{ Storage (day) } \\
\hline & $\begin{array}{l}\text { Initial } \\
\text { content }\end{array}$ & 1 & 2 & 3 & 7 & 14 & 21 & 28 \\
\hline \multicolumn{9}{|l|}{ B. licheniformis } \\
\hline $10^{2} \pm \mathrm{SD}$ & $\begin{array}{r}0.65 \\
+0.08\end{array}$ & $\begin{array}{r}0.71 \\
+0.12\end{array}$ & $\begin{array}{r}0.85 \\
+0.03\end{array}$ & $\begin{array}{r}1.03 \\
+008\end{array}$ & $\begin{array}{r}1.12 \\
+008\end{array}$ & $\begin{array}{r}1.39 \\
+018\end{array}$ & 1.51 & 1.58 \\
\hline $10^{1} \pm \mathrm{SD}$ & $\begin{array}{r}0.65 \\
\pm 0.08\end{array}$ & $\begin{array}{r}0.71 \\
\pm 0.10\end{array}$ & $\begin{array}{r}0.84 \\
\pm 0.04\end{array}$ & $\begin{array}{r}0.98 \\
\pm 0.07\end{array}$ & $\begin{array}{r}1.18 \\
\pm 0.07\end{array}$ & $\begin{array}{r}1.36 \\
\pm 0.15\end{array}$ & $\begin{array}{r}1.51 \\
+0.12\end{array}$ & $\begin{array}{r}1.59 \\
+0.17\end{array}$ \\
\hline$<10^{1} \pm \mathrm{SD}$ & $\begin{array}{r}0.65 \\
\pm 0.08\end{array}$ & $\begin{array}{r}0.66 \\
\pm 0.07\end{array}$ & $\begin{array}{r}0.75 \\
\pm 0.07\end{array}$ & $\begin{array}{r}0.84 \\
\pm 0.06\end{array}$ & $\begin{array}{r}0.98 \\
\pm 0.04\end{array}$ & $\begin{array}{r}1.14 \\
\pm 0.07\end{array}$ & $\begin{array}{r}1.27 \\
\pm 0.12\end{array}$ & $\begin{array}{r}1.34 \\
\pm 0.17\end{array}$ \\
\hline \multicolumn{9}{|l|}{ B. subtilis } \\
\hline $10^{2} \pm S D$ & $\begin{array}{r}0.65 \\
\pm 0.08\end{array}$ & $\begin{array}{r}0.69 \\
\pm 0.08\end{array}$ & $\begin{array}{r}0.73 \\
\pm 0.07\end{array}$ & $\begin{array}{r}0.81 \\
\pm 0.06\end{array}$ & $\begin{array}{r}0.99 \\
\pm 0.03\end{array}$ & $\begin{array}{r}1.04 \\
\pm 0.03\end{array}$ & $\begin{array}{r}1.19 \\
\pm 0.15\end{array}$ & $\begin{array}{r}1.28 \\
\pm 0.14\end{array}$ \\
\hline $10^{1} \pm \mathrm{SD}$ & $\begin{array}{r}0.65 \\
\pm 0.08\end{array}$ & $\begin{array}{r}0.67 \\
\pm 0.08\end{array}$ & $\begin{array}{r}0.72 \\
\pm 0.08\end{array}$ & $\begin{array}{r}0.82 \\
\pm 0.09\end{array}$ & $\begin{array}{r}0.90 \\
\pm 0.09\end{array}$ & $\begin{array}{r}1.05 \\
\pm 0.03\end{array}$ & $\begin{array}{r}1.18 \\
\pm 0.17\end{array}$ & $\begin{array}{r}1.26 \\
\pm 0.09\end{array}$ \\
\hline$<10^{1} \pm \mathrm{SD}$ & $\begin{array}{r}0.65 \\
\pm 0.08\end{array}$ & $\begin{array}{r}0.65 \\
\pm 0.08\end{array}$ & $\begin{array}{r}0.67 \\
\pm 0.07\end{array}$ & $\begin{array}{r}0.72 \\
\pm 0.08\end{array}$ & $\begin{array}{r}0.80 \\
\pm 0.08\end{array}$ & $\begin{array}{r}0.90 \\
\pm 0.10\end{array}$ & $\begin{array}{r}0.99 \\
\pm 0.45\end{array}$ & $\begin{array}{r}1.06 \\
\pm 0.05\end{array}$ \\
\hline \multicolumn{9}{|l|}{ B. cereus } \\
\hline $10^{2} \pm \mathrm{SD}$ & $\begin{array}{r}0.65 \\
\pm 0.08 \\
\end{array}$ & $\begin{array}{r}0.69 \\
+0.09 \\
\end{array}$ & $\begin{array}{r}0.97 \\
\pm 0.06 \\
\end{array}$ & $\begin{array}{r}1.18 \\
\pm 0.10 \\
\end{array}$ & $\begin{array}{r}1.42 \\
\pm 0.15 \\
\end{array}$ & $\begin{array}{r}1.66 \\
\pm 0.27 \\
\end{array}$ & $\begin{array}{r}2.01 \\
\pm 0.16 \\
\end{array}$ & $\begin{array}{r}2.13 \\
\pm 0.28 \\
\end{array}$ \\
\hline $10^{1} \pm \mathrm{SD}$ & $\begin{array}{r}0.65 \\
\pm 0.08\end{array}$ & $\begin{array}{r}0.69 \\
\pm 0.09\end{array}$ & $\begin{array}{r}0.89 \\
\pm 0.09\end{array}$ & $\begin{array}{r}1.09 \\
\pm 0.09\end{array}$ & $\begin{array}{r}1.36 \\
\pm 0.18\end{array}$ & $\begin{array}{r}1.62 \\
\pm 0.23\end{array}$ & $\begin{array}{r}1.88 \\
\pm 0.07\end{array}$ & $\begin{array}{r}2.09 \\
\pm 0.19\end{array}$ \\
\hline$<10^{1} \pm \mathrm{SD}$ & $\begin{array}{r}0.65 \\
\pm 0.08\end{array}$ & $\begin{array}{r}0.67 \\
\pm 0.08\end{array}$ & $\begin{array}{r}0.74 \\
\pm 0.11\end{array}$ & $\begin{array}{r}0.94 \\
\pm 0.09\end{array}$ & $\begin{array}{r}1.27 \\
\pm 0.17\end{array}$ & $\begin{array}{r}1.41 \\
\pm 0.22\end{array}$ & $\begin{array}{r}1.54 \\
\pm 0.28\end{array}$ & $\begin{array}{r}1.66 \\
\pm 0.25\end{array}$ \\
\hline
\end{tabular}

Table $2 b$

Content of free tyrosine (mg.ml-1) in the UHT milk with spores of B. licheniformis, B. subtilis, B. cereus after inactivation at $135^{\circ} \mathrm{C} 5 \mathrm{~s}$ in the course of storage (day) at $24^{\circ} \mathrm{C}$

\begin{tabular}{|c|c|c|c|c|c|c|c|c|}
\hline \multirow{2}{*}{$\begin{array}{l}\text { Initial concentration } \\
\text { of spores in } 1 \mathrm{ml} \\
\text { milk }\end{array}$} & \multicolumn{8}{|c|}{ Storage (day) } \\
\hline & 0 & 1 & 2 & 3 & 7 & 14 & 21 & 28 \\
\hline \multirow[t]{2}{*}{$10^{2} \pm \mathrm{SD}$} & 0.65 & 0.65 & 0.66 & 0.67 & 0.71 & 0.73 & 0.73 & 0.73 \\
\hline & \pm 0.08 & \pm 0.08 & \pm 0.08 & \pm 0.08 & \pm 0.15 & \pm 0.17 & \pm 0.18 & \pm 0.19 \\
\hline \multirow[t]{2}{*}{$10^{1} \pm \mathrm{SD}$} & 0.65 & 0.65 & 0.65 & 0.66 & 0.66 & 0.66 & 0.66 & 0.66 \\
\hline & \pm 0.08 & \pm 0.08 & \pm 0.07 & \pm 0.08 & \pm 0.09 & \pm 0.05 & \pm 0.48 & \pm 0.05 \\
\hline \multirow[t]{2}{*}{$<10^{1} \pm \mathrm{SD}$} & 0.65 & 0.65 & 0.65 & 0.65 & 0.66 & 0.65 & 0.65 & 0.66 \\
\hline & \pm 0.08 & \pm 0.08 & \pm 0.08 & \pm 0.08 & \pm 0.01 & \pm 0.08 & \pm 0.08 & \pm 0.08 \\
\hline
\end{tabular}

spore concentrations and $1.66 \mathrm{mg} \cdot \mathrm{ml}^{-1}$ in case of $<10^{1} \cdot \mathrm{ml}^{-1}$ concentration. The lowest range of protein breakdown was detected in milk inoculated with $B$. subtilis spores, when the free tyrosine contents increased only to $1.06-1.26$ and $1.28 \mathrm{mg} \cdot \mathrm{ml}^{-1}$. When studying the proteolytic activities of psychrotrophic microorganisms in milk, Lukášová (1985) detected an increase of free tyrosine up to $1.21 \mathrm{mg} \cdot \mathrm{ml}^{-1}$ at $10^{8} \mathrm{CFU} \cdot \mathrm{ml}^{-1}$, which corresponds to values detected by us while reaching the same number of microorganisms (Table $2 a, 2 b$ ). The detected free tyrosine for B. subtilis was - in comparison with B. licheniformis - 
significantly lower $(p<0.05)$ and in comparison with $B$. cereus significantly lower $(p<0.01)$. Just to the contrary, the highest content was recorded for B. cereus.

When spores inactivated by heating to $100^{\circ} \mathrm{C}$ for $10 \mathrm{~min}$ and $135^{\circ} \mathrm{C}$ for $5 \mathrm{~s}$ were used, proteolysis occurred (with samples stored at room temperature) only with one strain of $B$. licheniformis under conditions of higher initial concentration of spores. The surviving spores sprout up and the protein contents was reduced to $33.3-31.1 \mathrm{~g} \cdot \mathrm{l}^{-1}$ and $33.8-33.05 \mathrm{~g} \cdot \mathrm{l}^{-1}$ and free tyrosine contents increased to $0.73 \mathrm{mg} \cdot \mathrm{ml}^{-1}$. After heating the spores of other strains of $B$. licheniformis as well as spores of $B$. subtilis and $B$. cereus their decomposition occurred (Tables $1 \mathrm{~b}, 1 \mathrm{c}, 2 \mathrm{~b}$ ).

Most authors used the capillary method or the method of gel electrophoresis and different types of gels (García-Risco et al. 1999; Recio et al. 2000) when monitoring proteolysis. Proteases produced by $B$. licheniformis cleave primarily the $\kappa$-casein. Johnston and Bruce (1982) monitored the occurrence of Bacillus spp. and effects of produced enzymes at milk components and they proved significant biochemical activity - casein hydrolysis in $84 \%$ of raw milk samples. The results of hydrolysis include de-stabilisation of casein micelles and milk coagulation (Is mail et al. 1991).

Based on our results it can be seen that significant $(p<0.05)$ or highly significant $(p<$ $0.01)$ reduction of casein fraction contents occurred only in samples stored at $24^{\circ} \mathrm{C}$. At this temperature, the highest reduction of $\kappa$-casein contents was recorded which dropped to $7.43 \%$. Moreover, $\beta$-casein was hydrolysed to $27.53 \%$. The $\alpha$-casein $43.95 \%$ (Fig. 1a and 2a) was assessed as the most stable one. In samples stored at $4{ }^{\circ} \mathrm{C}-$ in comparison with the initial contents of casein fractions - no significant reduction of their contents due to any of the monitored strains of $B$. licheniformis was found. In the course of storage, the contents of $\kappa$-casein dropped to $79.42 \%, \beta$-casein to $78.30 \%$ and $\alpha$-casein to $85.71 \%$ (Plate VII, Fig. $1 \mathrm{~b}$ and $2 \mathrm{~b}$ ). López-Fandiño et al. (1993) obtained similar results when monitoring the effects of proteasis Pseudomonas fluorescens B52 to proteins in directly and indirectly treated skimmed and full UHT milk, stored for the period of 78 days at $22{ }^{\circ} \mathrm{C}$. The highest reduction was recorded for $\kappa$-casein fraction. The $\alpha$-casein was assessed to be the most stable fraction. Identical results were obtained also by Is mail et al. (1991), and Dogru et al. (2001). Gallagher et al. (1994) monitored the effects of protease of B. subtilis and its optimal temperature of $40^{\circ} \mathrm{C}$ for casein fractions. After $1 \mathrm{~h}$, the $\alpha$-casein was stable, while $\beta$-casein was fully hydrolysed within 40 minutes. Alfa-casein and $\beta$-casein are selectively attacked depending on the microorganism type (Shah 1994).

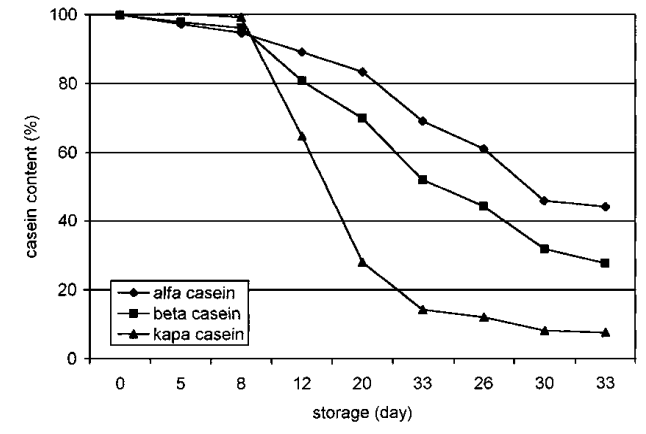

Fig. 1a. Proteolytic influence of Bacillus licheniformis on casein fractions in the UHT milk stored at $24{ }^{\circ} \mathrm{C}$

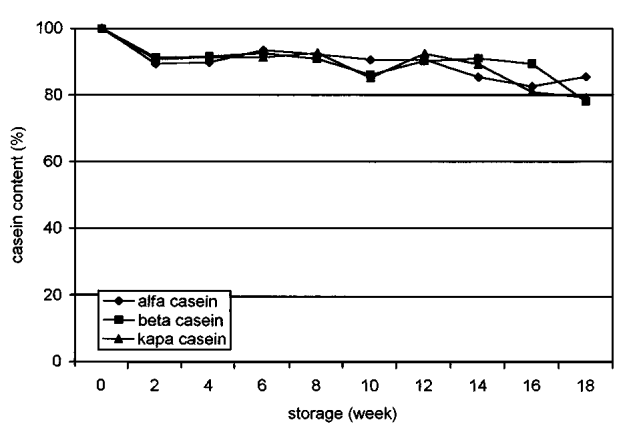

Fig. 2a. Proteolytic influence of Bacillus licheniformis on casein fractions in the UHT milk stored at $4{ }^{\circ} \mathrm{C}$

\section{Vliv enzymů Bacillus spp. na bílkoviny UHT mléka}

Na modelovém případě kontaminace trvanlivého polotučného mléka spórami 15 kmenů $B$. licheniformis, $B$. subtilis a $B$. cereus izolovaných z prostředí farmy a ze syrového mléka 
bylo provedeno sledování proteolýzy stanovením změn obsahu bílkovin metodou infračervené spektroskopie, volného tyrosinu Lowryho metodou podle Juffse a stanovením úbytku kaseinových frakcí pomocí SDS-PAGE.

Při skladovací teplotě $4{ }^{\circ} \mathrm{C}$ nebyla proteolýza zaznamenána, zatímco při skladovací teplotě $24^{\circ} \mathrm{C}$ byly zjištěny po 3 týdnech následující změny od původních hodnot: pokles bílkovin z $34.60 \mathrm{~g} \cdot \mathrm{l}^{-1}$ mléka na hodnoty $29.46-32.86 \mathrm{~g} \cdot \mathrm{l}^{-1} \mathrm{mléka}$ a zvýšení obsahu volného tyrosinu z $0.65 \mathrm{mg} \cdot \mathrm{ml}^{-1}$ na hodnoty $2.13-1.59 \mathrm{mg} \cdot \mathrm{ml}^{-1}$ mléka v závislosti na druhu Bacillus spp.. Bylo zjištěno, že teplotní a časový parametr záhřevu na $100{ }^{\circ} \mathrm{C} 10$ minut a $135^{\circ} \mathrm{C} 5$ sekund mohou spóry rezistentních kmenů Bacillus licheniformis přežít a vykazovat proteolytickou aktivitu.

Při sledování úbytku kaseinových frakcí bylo zjištěno, že nejrychleji byl odbouráván $\kappa$ kasein na $7.43 \%$. Hodnoty $\beta$-kaseinu poklesly na $27.53 \%$ a $\alpha$-kaseinu na $43.95 \%$. Při skladovací teplotě $4{ }^{\circ} \mathrm{C}$ byl úbytek všech kaseinových frakcí nižší. Došlo k poklesu na $79.42 \%$ pro $\kappa$-kasein, $78.30 \%$ pro $\beta$-kasein a $85.71 \%$ pro $\alpha$-kasein.

Intenzita změn byla závislá na použitém druhu i kmenu Bacillus spp., skladovací teplotě a výši tepelné inaktivace spór. Částečně se projevil vliv použité výchozí koncentrace spór.

\section{Acknowledgements}

This study was supported by grant of ministry of Education, Youth and Sports of the Czech Republic No 162700005 .

\section{References}

BAHOUT, AA 2000: Prevalence of Bacillus species in UHT milk. Assiut-Veterinary- medical-Journal 42: 47-53 BOOR, KJ, BROWN, DP, MURPHY, SC, KOZLOWSKI, SM, BANDLER, DK 1998: Microbiological a Chemical Quality of Raw Milk in New York State. J Dairy Sci 81: 1743-1748

BROWN, KL 2000: Control of bacterial spores. Brit Med Bull 56: 158-171

CORZO, A, LÓPEZ-FANDIÑO, R, DELGEDO, T, RAMOS, M., OLANO, A 1994: Changes in furosine and proteins of UHT treated milks stored at high ambient temperatures. Lebensm Unters Forsch 198: 302-306

CRIELLY, EM, LOGAN, NA, ANDERTON, A 1994: Studies on the Bacillus flora of milk and milk products. J Appl Bacteriol 77: 256-263

DATTA, N, DEETH, HC 2001: Age gelation of UHT milk - A review. Food Bioprod Process 79: 197-210

DALGLEISH, DG 1990: Denaturation and aggregation of serum proteins and casein in heated milk. J Agric Food Chem 38: 1995-1999

DOGRU, M, BAYSAL, Z, AYTEKIN, C 2001: Suitability of animals' purified milk caseins and their subunit kcaseins as substrates for subtilisin and trypsin. Prep Biochem Biotechnol 31: 147-154

GALLAGHER, J, KANEKANIAN, AD, EVANS, EP 1994: Hydrolysis of casein: a comparative study of two proteases and their peptide maps. Int J Food Sci Technol 29: 279-285

GARCÍA-RISCO, MR, RAMOS, M, LÓPEZ-FANDIÑO, R 1999: Proteolysis, protein distribution and stability of UHT milk during storage at room temperature. J Sci Food Agric 79: 1171-1178

IPSEN, R, OTTE, J, LOMHOLT, SB, QVIST, KB 2000: Standardized reaction times used to describe the mechanism of enzyme-induced gelation in whey protein systems. J Dairy Res 37: 403-413

ISMAIL, AA, EFFAT, BM, EL-SAMRAGY, YA, MAGDOUB, MNI 1991: Production of proteases by some dairy psychrotrophic bacteria. Annals Agric Sci 36: 525-534

JOHNSTON, DW, BRUCE, J 1982: Incidence of thermoduric psychrotrophs in milk produced in the West of Scotland. J Appl Bacteriol 53: 333-337

JUFFS, HS 1973: Proteolysis detection in milk.I. Interpretation of tyrosine value data for raw milk supplies in relation to natural variation, bacterial counts and other factors. J Dairy Res 40: 371-381

KAVANAGH, GM, CLARK, AH, ROSS-MURPHY, SB 2000: Heat-induced gelation of globular proteins: part 3. Molecular studies on low pH beta-lactoglobulin gels. Int J Biol Macromol 28: 41-50

KELLY, AL, FOLEY, J 1997: Proteolysis and storage stability of UHT milk as influenced by milk plasmin activity, plasmin/beta - lactoglobulin complexation, plasminogen activation and somatic cell count. Int Dairy J 7: 411-420

LAEMMLI, UK 1970: Cleavage of structural proteins during the assembly of the head of bacteriophage T4. Nature 227: 680-685

LÓPEZ - FANDIÑO, R, OLANO, A, CORZO, N, RAMOS, M 1993: Proteolysis during storage of UHT milk: differences between whole and skim milk. J Dairy Res 60: 339-347

LUKÁŠOVÁ, J 1985: The effect of bacterial proteases on milk proteins. Vet Med-Czech 30: 699-703

LUKÁŠOVÁ, J, VYHNÁLKOVÁ, J, PÁČOVÁ,Z 2001: Bacillus species in raw milk and in the farm environment. 
Milchwissenschaft 56: 609-611

MADSEN, JS, QVIST, KB 1997: Hydrolysis of milk protein by Bacillus licheniformis protease specific for acidic amino acid residues. J Food Sci 62: 579-582

MARTH, EH, STEELE, JL 1998: Applied Dairy Microbiology. Marcel Decker, INC, New York, 516 p.

MATOUŠKOVÁ, O, CHALUPA, J, CÍGLER, M, HRUŠKA, K. STAT-Plus uživatelská příručka, verse 1.01., 1992. Veterinary Research Institute, Brno, CR

Mc MAHON, DJ 1996: Age-gelation of UHT milk: Changes that occur during storage on shelf-life and the mechanism by which age-gelation occurs. Heat treatments and alternative methods. International Dairy Federation - Ref.SI 9602, Vienna, Austria, p. 315-325. In DATTA, A., DEETH, HC 2001: Age gelation of UHT milk - A review. Food Bioprod Process 79: 197-210

MEER, RR, BAKER, FW, BODYFELT, FW, GRIFFITHS, MW 1991: Psychrotrophic Bacillus spp. in fluid milk products. A review. J Food Protect 54: 969-979

PÁČOVÁ, Z, VYHNÁLKOVÁ, J, LUKÁŠOVÁ, J, HOLEC, J 1996: Identification of aerobic and facultatively anaerobic sporulating bacteria isolated from operations of milk primary production. Vet Med-Czech 41: 19-23 PHILLIPS, JD, GRIFFITHS, MW 1986: Factors contributing to the seasonal variation of Bacillus spp. in pasteurized dairy products. J Appl Bacteriol 61: 275-285

RECIO, I, GARCÍA-RISCO, MR, RAMOS, M, LÓPEZ-FANDIÑO, R 2000: Characterization of peptides produced by the action of psychrotrophic proteinases on $\kappa$ - casein. J Dairy Res 67: 625-630

SHAH, NP 1994: Psychrotrophs in milk: a review. Milchwissenschaft 49: 432-437

SWAISGOOD, HE 1993: Review and update of casein chemistry. J Dairy Sci 76: 3054-3061

VYLETĚLOVÁ, M, HANUŠ, O, URBANOVÁ, E, KOPUNECZ, P 2000: The occurrence and identification of psychrotrophic bacteria with proteolytic and lipolytic activity in bulk milk samples at storage in primary production conditions. Czech J Anim Sci 45: 373-383

VYLETĚLOVÁ, M 2001: Výskyt bakterií rodu Bacillus v syrovém, pasterovaném a UHT mléce. Náš chov 5: 16-18

VYLETĚLOVÁ, M, HANUŠ, O, PÁČOVÁ, Z, ROUBAL, P, KOPUNECZ, P 2001: Frequency of Bacillus bacteria in raw cows' milk and relation to other hygiene parameters. Czech J Anim Sci 46: 260-267

ZHAO, L, QI, J, GAO, JA 1998: Kinetics study on the production of alkaline proteinase by Bacillus licheniformis 2709. Chin J Biotechnol 14: 241-247 


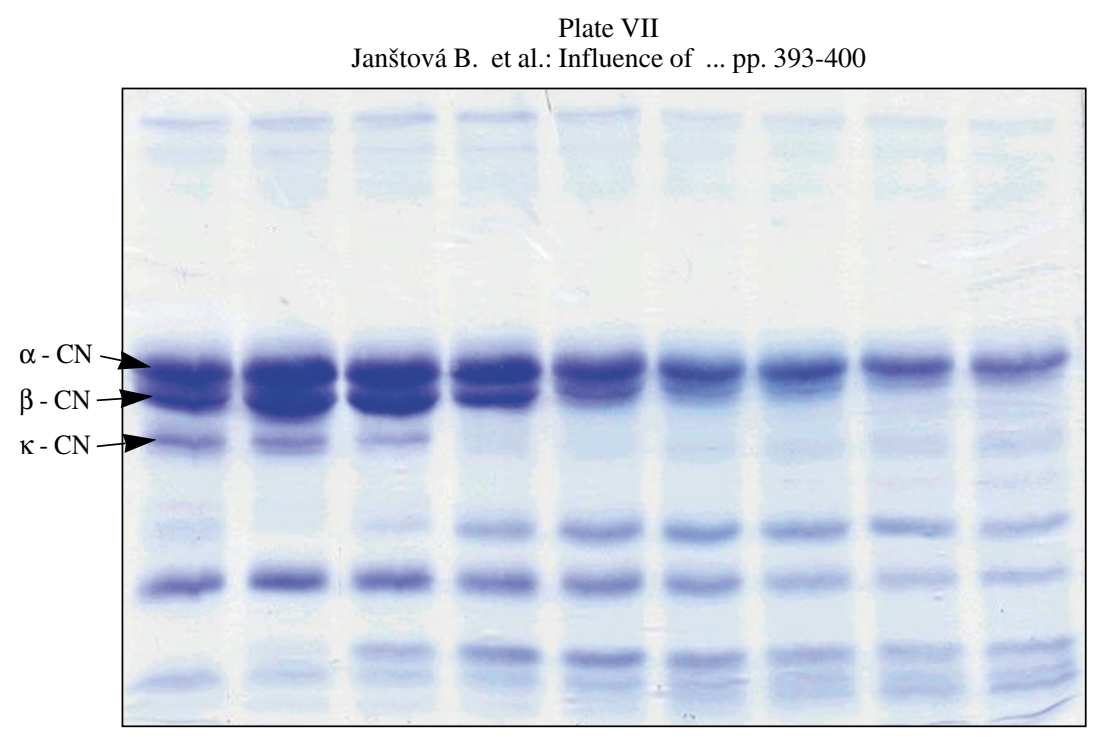

Fig. 1b. SDS-PAGE pattern of casein fractions proteolysis by Bacillus licheniformis of storage UHT milk at $24{ }^{\circ} \mathrm{C}$. The number at the lines means week of storage.

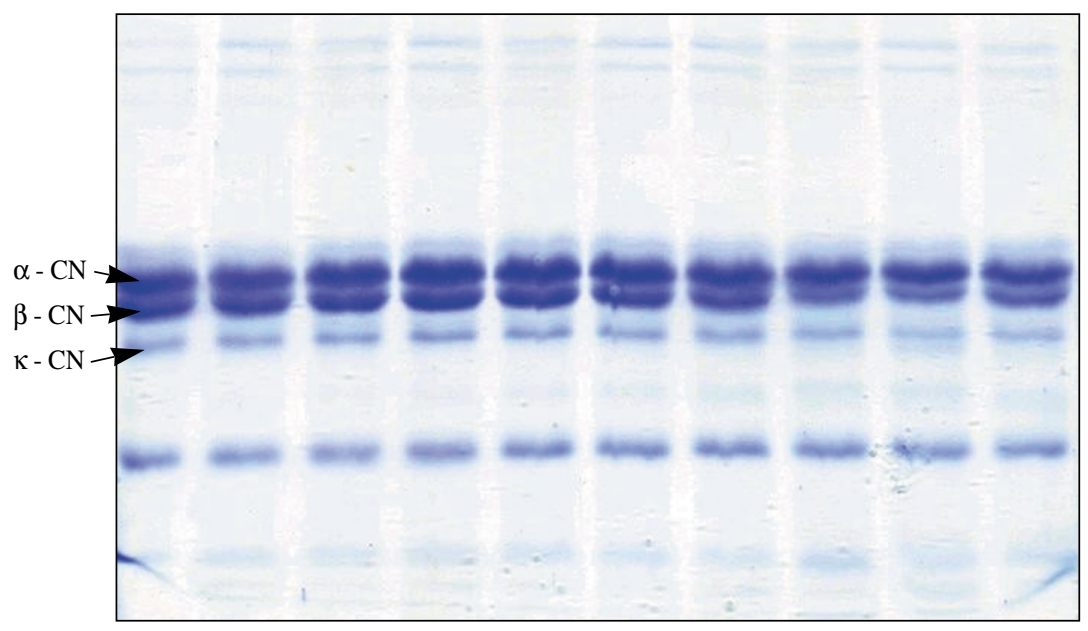

Fig. 2b. SDS-PAGE pattern of casein fractions proteolysis by Bacillus licheniformis of storage UHT milk at $4{ }^{\circ} \mathrm{C}$. The number at the lines means week of storage. 